\title{
Illegal immigration: \\ Policy perspectives and challenges
}

\author{
Alessandra Casarico*, Giovanni Facchini**, Tommaso Frattini***
}

\begin{abstract}
The combination of increasing immigration pressures and restrictive policies imperfectly enforced by many destination countries has made illegal immigration widespread. This paper provides an overview of the mechanisms behind the formation of migration policies and how they lead to or they limit the presence of illegal immigrants. We also study how governments deal ex-post with the presence of undocumented foreign workers by introducing immigration amnesties. We review the determinants of their introduction and address their desirability from the point of view of aggregate welfare. As countries in the EU differ substantially in the implementation of both ex-ante and ex-post immigration policies, we emphasize the need for more coordination in the area of migration policy enforcement, both at the border and within each country.
\end{abstract}

* Università Commerciale Luigi Bocconi, Dondena Center for Research on Social Dynamics and Public Policy, Centro Studi Luca d'Agliano (LdA) and CES-Ifo. E-Mail: alessandra.casarico@unibocconi.it.** University of Nottingham, Università degli Studi di Milano, Centro Studi Luca D'Agliano (LdA), CEPR, CES-Ifo, CReAM, GEP and IZA. EMail: giovanni.facchini@ nottingham.ac.uk.*** Università degli Studi di Milano, Centro Studi Luca D’Agliano (LdA), CReAM and IZA. E-mail: tommaso.frattini@unimi.it. This paper is part of the CEPR project "Temporary Migration, Integration and the role of Policies" (TEMPO) funded by the NORFACE Research Programme: "Migration in Europe Social, Economic, Cultural and Policy Dynamics." We would like to thank participants to the CES Ifo Economic Studies Conference on Migration, the editors and one anonymous referee for useful comments. 


\section{Introduction}

Illegal immigration refers to an act of migration that is carried out against legal provisions of entry and/or residence in the destination country. There are many possible avenues through which an individual might become an illegal immigrant. Citizens from nations which do not have automatic visa waiver agreements, or who would not qualify otherwise for a visa, often enter their destination country by crossing the border without inspection (illegally). Alternatively, individuals might become illegal immigrants by simply overstaying the period of legal permanence in the country. Similarly, unauthorized immigrants who have been denied asylum or temporary protected status and continue to be in the destination country are considered to be unauthorized residents.

More generally, illegal immigration comes about because most countries have in place measures to limit the inflow of foreign nationals, which are not perfectly enforced. Growing migration pressures in the presence of restrictive policies have contributed to make the phenomenon widespread, and illegal immigration features prominently in the public debate (Facchini, Mayda and Puglisi 2011). Yet, there are important differences both in terms of the stocks (and flows) of undocumented foreign nationals, and the policies which are adopted to handle them once they are in the host country. Table 1 (taken from Dustmann and Frattini 2013) gives an overview of the size of the phenomenon in the main destinations.

The best available estimates suggest that in $2009,3.5 \%$ of the total population in the United States was made up by irregular migrants. This means that almost one out three immigrants was in the country illegally. In Europe the figures are on average much lower, but there is substantial heterogeneity across countries. The phenomenon is basically absent in Norway or Denmark, very small in countries like Finland, Sweden or Germany, while it is instead sizeable in the United Kingdom, the Netherlands, Greece and Italy. In the UK for instance, between one out of eight and one out of four immigrants violates the local legal provisions, and only slightly smaller figures apply to the case of Greece and of the Netherlands. Triandafyllidou and Vogel (2010) point out that "status-related flows" are much more important in Europe than the "geographic flows" that instead play a key role in the United States in generating irregular migrants. This is true even if smuggling foreign workers across borders is much more likely to catch newspapers' headlines. For instance, despite the media coverage given to the arrival of undocumented migrants on Italian Southern shores, data from the Italian Ministry of Internal Affairs suggest that between 2000-2006 over two thirds of the undocumented immigrants in Italy were visa overstayers, i.e. individuals who entered the country with a legal visa but that did not leave once the visa expired (Fasani, 2010).

The goal of this paper is to provide an overview of how illegal immigration comes about, i.e. of the process through which restrictive immigration policies are formed and their imperfect enforcement leads to the presence of illegal immigrants. We will start by exploring the role played by individual preferences and discuss how they are aggregated into a policy outcome in democratic societies (section 2). We will then focus on the measures that can be adopted to limit the stock of illegal immigrants (section 3). In section 4 we consider one instrument which has often been used to deal with illegal immigration ex-post, namely an immigration amnesty. We will look at some new results on what determines the introduction of a broad 
legalization program in a sample of OECD countries, and discuss the desirability, from the point of view of aggregate welfare, of using this instrument in the first place. Section 5 concludes our analysis, highlighting the need for more coordination in the enforcement of immigration policies among countries in the European Union, where (irregular) workers are free to move across national borders.

\section{The political economy of illegal immigration}

As we have already argued, illegal immigration comes about because most destination countries set policies to limit the legal inflow of foreign workers. What drives the formation of these policies in the first place? In this section we review the explanations that have been proposed in the economics literature, while referring the interested reader to the insightful papers by, Espenshade and Colahun (1993), Joppke (1998), Berg (2009) and Ceobanu and Escandell (2010) for perspectives from other social sciences.

A useful conceptual framework to study the process by which economic policies come about has been proposed by Rodrik (1995) and adapted to the study of immigration policy by Facchini and Mayda (2010). The scheme is illustrated in figure 1 below. The basic idea is that the formation of immigration policies is the result of the actions carried out by several groups of agents, and can be thought of as the equilibrium outcome of the interaction between a "policy demand" and a "policy supply".

On the demand side, the preferences of individual agents towards the inflow of foreign workers, legal and illegal, are the primitives in the problem of the policy maker. These preferences are shaped by a variety of economic and non-economic factors, and much attention has been dedicated by the political economy literature to the process by which these preferences are aggregated into a policy demand. Various channels have been highlighted, starting from the role of grass roots movements, to political parties and pressure groups. On the supply side of migration policies, we need to identify the relevant policy maker's preferences and to understand the institutional framework in which he comes to operate. Building on this framework, we start by investigating the drivers of individual preferences towards immigration.

\subsection{What drives individual attitudes towards illegal immigration?}

A large body of literature has studied the drivers of individual preferences towards immigration, highlighting the role of both economic and non-economic factors. There is instead much less evidence on what drives attitudes towards illegal immigration in particular. We start by discussing the determinants of attitudes towards overall immigration, and turn next to investigate the drivers of preferences towards illegal immigration. 
Figure 1: Determination of immigration policy

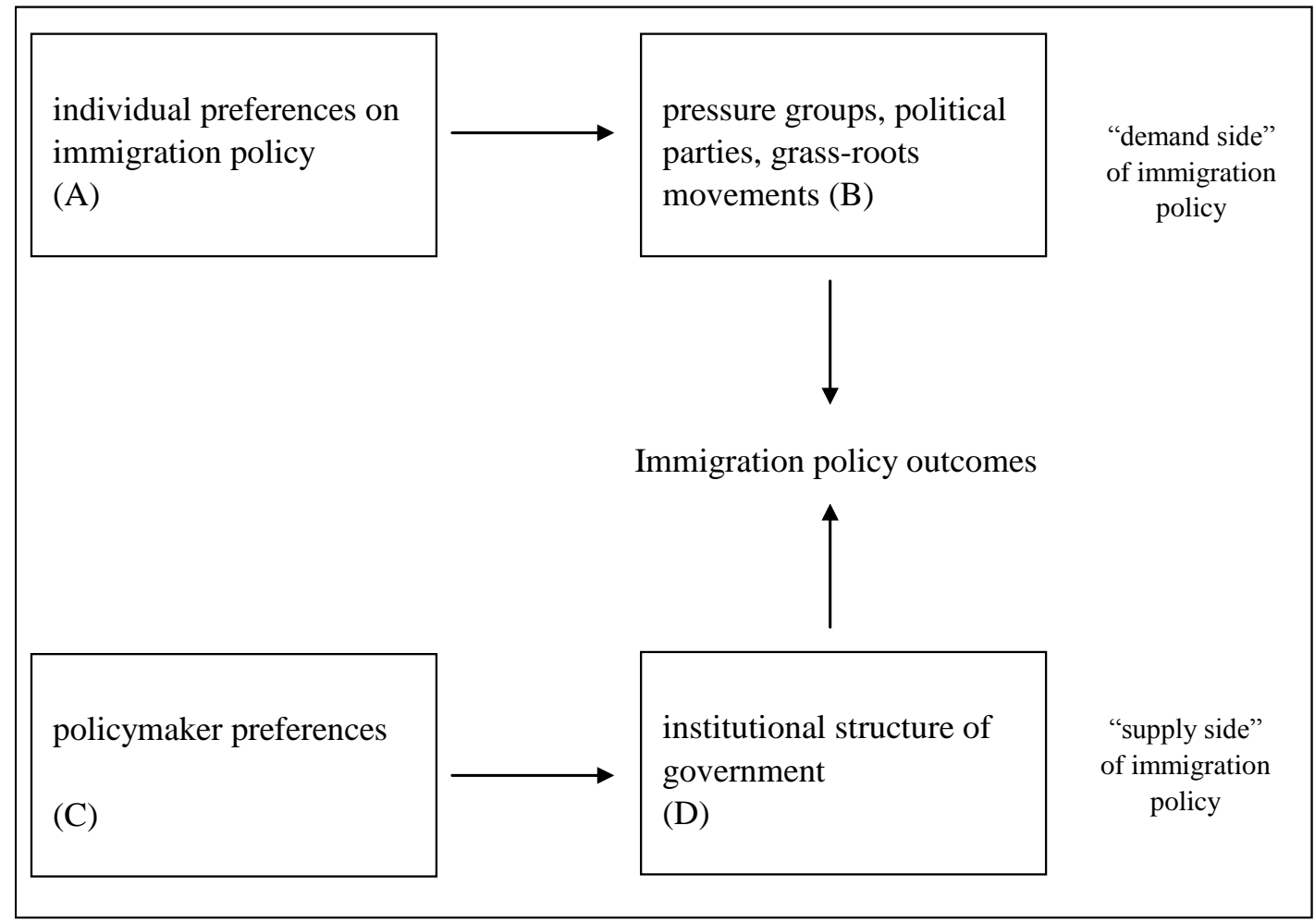

In modeling the role of economic drivers, the existing literature has assumed that individual respondents are characterized by self-interest maximizing behavior. As a result, in forming their opinion, agents consider the impact of migration on their own utility. Since the economic consequences of migration are uneven across the population, the main economic drivers of attitudes are associated with the incomedistribution effects of migration. Two mechanisms have been studied in detail: the labor market and the welfare state channels. To understand the working of the former, assume that skilled and unskilled labor are combined to produce a single good according to a constant returns to scale production function. Theory predicts that, through substitutability and complementarity in production, the income-distribution effects of migration depend on the skill composition of migrants relative to natives in the destination country (see Benhabib 1996, Borjas 1999). If immigrants are on average less skilled than natives, skilled workers will benefit from migration, while unskilled workers will be on the losing end. The reason is that the arrival of immigrants will tend to decrease the unskilled wage, whereas it will increase the skilled one. If, on the other hand, immigrants are on average more skilled than natives, the labor market effects of migration are reversed, i.e. immigrants will hurt skilled natives and benefit unskilled ones, as their arrival will induce a decrease in the skilled wage and an increase in the unskilled one. Therefore, the empirical prediction of this simple model is that, in countries which receive more unskilled migrants (relative to natives), a positive relationship should hold between voters' individual skill and pro-immigration attitudes whereas, in countries which receive more skilled migrants, a negative relationship should be observed. 
The empirical evidence in the literature is broadly consistent with these theoretical predictions. In an early contribution, Scheve and Slaughter (2001) find that, in the United States, unskilled workers are more likely to oppose immigration, relative to skilled workers. This result is consistent with the labor market competition hypothesis outlined above: since immigrants in the U.S. are on average less skilled than natives, they compete with unskilled workers in the labor market. Broadly similar results have been obtained also by Dustmann and Preston $(2001,2007)$ using UK data. ${ }^{1}$

One concern that could arise in assessing the results of studies based on one-country data- where all the receiving countries separately analyzed in the literature are rich and tend to receive unskilled migrants is that the positive correlation observed between skill and pro-migration attitudes could be driven by noneconomic considerations - rather than labor-market competition - as pointed out by Hainmueller and Hiscox (2007). For example, more educated individuals might be more pro-migration because they are more open to different cultures, more cosmopolitan and more tolerant. Scheve and Slaughter (2001) explicitly address this possibility, and show that the impact of individual skill on pro-migration preferences disappears for individuals out of the labor force. This result is evidence in support of the labor market competition hypothesis and against an interpretation of the skill-attitudes correlation based only on non-economic factors.

Another way to confirm the robustness of the labor-market competition result is to carry out a crosscountry analysis. By doing so, researchers are able to exploit the variation in the composition of the immigrant population across different destinations. According to the economic model, educated respondents should be more favorable to immigration only in countries which tend to receive unskilled migrants (high per capita GDP countries) while they should be less supportive in countries which tend to receive migrants who are more skilled relative to the native population. If education were just a proxy for openness to different cultures, we would not expect this relation to hold. Mayda (2006) carries out one of the first cross-country analyses and finds evidence which is very consistent with the labor-market competition predictions: individual skill is positively correlated with pro-immigration attitudes in countries where immigrants are on average unskilled, while it is negatively correlated with attitudes in countries where immigrants are on average skilled, relative to the native population. Facchini and Mayda (2008) show that the labor market effects are robust when considering surveys carried out in different time periods. Ortega and Polavieja (2012) find similar results, emphasizing how the attitudes of natives are more likely to react to the presence of immigrants when their exposure to competition in the labor market increases, because, for instance, they are employed in a manual occupation, which requires limited communication skills.

The second economic driver highlighted in the literature is the welfare state. The main OECD destination countries are characterized by large welfare states (Boeri, Hanson and McCormick 2002), through which the public sector redistributes a substantial fraction of national income across individuals. In these contexts, immigration has a non-negligible impact on public finances, since foreign workers both contribute to and benefit from the welfare state. The aggregate net effect of immigration on the welfare state

\footnotetext{
${ }^{1}$ For a more critical perspective, see Blonigen (2011).
} 
is either positive or negative, depending on the socio-economic characteristics of immigrants relative to natives. This aggregate effect will also affect the post migration net income distribution and, as the recent literature has shown, this is important to understand public opinion on immigration (Mueller and Tai 2009).

In their analysis of attitudes towards immigration in the US states, Hanson, Scheve and Slaughter (2007) find evidence that the positive correlation between pro-immigration attitudes and education, driven by the labor market, becomes smaller in absolute value and even negative in US states in which the fiscal exposure to immigration is high. This evidence suggests that individuals expect the welfare state to react to the presence of immigrants through changes in the tax rates, as individual income and education are positively correlated, and immigration to the United States tends on average to be unskilled. Similar evidence has also been obtained by Facchini and Mayda (2009) in a cross country study that has used the 1995 round of the International Social Survey Panel and the 2003 round of the European Social Survey.

Besides economic drivers, Scheve and Slaughter (2001), Mayda (2006) and Facchini and Mayda (2009) consider also the role of non-economic factors such as the perceived crime and cultural impact of immigration, the role played by racism, sciovinism etc., even though these factors are not the focus of their analyses. As also argued by Dustmann and Preston (2007), all these elements do play an important role in shaping attitudes towards immigration.

What are the individual preferences towards illegal immigrations? What are the factors that shape them? As mentioned before, the economics literature on this matter is rather scant, notwithstanding the prominence of the issue on the policy agenda. A possible explanation is the limited availability of survey data in which illegal immigration is explicitly considered. An important exception is the 2003 round of the International Social Survey Programme (ISSP Research Group, 2012). Interestingly, this dataset allows carrying out a broad comparison between attitudes towards overall immigration, and a measure of opinions towards illegal immigration. To that end we can consider two questions. The first one focuses on overall immigration and has been used by several researchers in the past. It asks "Do you think the number of immigrants to [COUNTRY] nowadays should be...", and the five possible answers are "1. Increased a lot", "2. Increased a little", "3. Remain the same", "4. Reduced a little" and "5. Reduced a lot". The second one focuses instead on illegal immigration, and asks "How much do you agree or disagree with the following statements?.[COUNTRY] should take stronger measures to exclude illegal immigrants", and the five possible answers are "1. Agree strongly", "2. Agree", "3. Neither agree nor disagree", "4. Disagree" and "5. Disagree strongly". To compare the two questions, we have rescaled the answers to the first so that a higher number corresponds to an increase in the openness towards immigration. The aggregate results for advanced destination countries are reported in Table 2 . The first two columns contain the average and the median value of the indicator for overall immigration, while the latter two report the same figures for illegal immigration.

There is substantial heterogeneity across countries both in attitudes towards overall immigration and towards illegal immigration in particular. As for the former, individuals based in Great Britain, Germany and Russia appear to have particularly negative views towards immigration. Respondents based in Canada, Australia and Finland are instead the most open. Turning to illegal immigration, individuals based in 
Bulgaria, the Czech Republic, Hungary and Japan feel particularly strongly about the need for their government to take a tougher stand against the phenomenon. Respondents based in Spain, Poland and Portugal appear instead to be less concerned with this issue.

Interestingly, comparing column (1) and column (3) (and column (2) and column (4)), we can see that respondents in the vast majority of the countries considered in the sample appear to hold more negative views towards illegal immigration than overall immigration, an unsurprising outcome, given that illegal immigrants are often perceived to be competing unfairly with natives by taking jobs in the informal sector, to be not paying their way through the welfare system, and to be more likely to end up in the criminal sector.

This differential attitude toward legal and illegal immigration is confirmed also by an analysis of more recent data from the Transatlantic Trends: Immigration 2010 (Wunderlich et al., 2010), that are available only for eight countries: Canada, France, Germany, Italy, the Netherlands, Spain, the UK and the US. In particular, the survey asks two similar questions on legal and illegal immigration: "Can you tell me if you are worried or not worried about legal immigration?" and "Can you tell me if you are worried or not worried about illegal immigration?". The possible answers are only "yes" or "no". Table 3 reports the share of individuals who declared to be worried by legal (column 1) and illegal (column 2) immigration, in each of the six countries covered by the survey. The difference between the two columns is striking: while the share of population worried by legal immigration ranges between 18\%, in the US and France, and 35\%, in the UK, the fraction of respondents who are worried about illegal immigration is between 53\% in Canada and $83 \%$ in Italy.

The analysis of the drivers of attitudes towards illegal immigration which we have just described is sparse. In one of the few studies looking at the role played by economic factors, Fino (2010) uses the ISSP dataset to compare the drivers of preferences towards immigration in general, and towards illegal immigration in particular. She finds that economic factors do play a role in shaping preferences towards illegal immigrants. In particular, less skilled individuals are more likely to oppose illegal immigration, and this result is compatible with a labor market competition story, as illegal immigrants tend to be less skilled than legal migrants, and be close substitutes of less educated domestic workers. At the same time, she does not find evidence for a role played by the welfare state.

Facchini, Mayda and Puglisi (2011) have instead used the Cooperative Congressional Election Study (CCES) survey, which was carried out in the United States around the 2006 midterm election, to look at the effect of non-economic drivers. In particular, using a question on individual preferences towards the immigration reform that was being discussed in the Senate at the time, they focus on the role played by different media outlets in shaping individual attitudes towards illegal immigration in general, and towards the path to legalization that was entailed in the reform. Interestingly, they find that media exposure does affect preferences, and in particular that viewers exposed to Lou Dobbs' strong anti-immigration rhetoric were nine percentage points more likely to be against legalization than CBS viewers.

\subsection{From individual preferences to migration policy}


Individual preferences are aggregated and become political demands as a result of the working of grass-root movements, political parties and/or interest groups (box B in Figure 1). This process is clearly affected by how severe the collective action problem is for certain groups. Such severity is in turn driven by several factors, for example the geographic or sectorial concentration of members of a group.

On the supply side of migration policy, government preferences play an important role (box C). Are officials interested in aggregate welfare, i.e. do they just wish to maximize society's well being? Do they care only about being re-elected, i.e. do they try to please the majority? Are their choices driven by ideological considerations? Are policymakers particularly responsive to the demands of specific groups within society, i.e. do they use migration policy as a tool to transfer resources to a specific group? Finally, is the institutional structure of the government, i.e. for instance which body is in charge of setting migration policy, likely to be an important factor in shaping the policy (box D)?.

The extent of detail to which the policy making process is analyzed varies greatly in the existing models. Whereas quite a bit of attention has been dedicated to the process through which individual preferences are aggregated, the policy makers preferences are typically described in a very reduced form fashion, ${ }^{2}$ and limited attention has been paid to the details of the institutional setting in which migration policy is set and enforced. More work needs to be done in this area, as the destination countries vary substantially in their political institutions. In the remainder of this section, we will describe the two main frameworks which have been proposed by the literature, i.e. the median voter and the pressure group models.

\subsubsection{The median voter framework}

The median voter model has been used to illustrate the migration policy formation process by Benhabib (1996), and extended by Ortega (2005). In both papers the authors assume that the enforcement of the measures introduced by the host country governments to limit immigration flows is costless, and that the supply of potential immigrants is perfectly known. As a result, neither of these models can explain the presence of illegal immigrants.

To capture instead this possibility, Facchini and Testa (2012) develop an alternative framework in which an elected politician faces uncertainty on the supply of potential migrants and needs to invest resources in order to enforce the official migration target he sets. In this model the authors envision the possibility that illegal immigration might just be the results of informational constraints faced by the government and model the role of political economy forces (see Hanson and Spilimbergo 2001 and Fasani 2009) in shaping the extent of migration policy enforcement. They build a simple two-period political

\footnotetext{
${ }^{2}$ Two interesting exceptions are the recent models by Solano-Garcia (2006) and Llavador and Solano-Garcia (2011), where the migration preferences of political parties competing in elections are explicitly modelled. In particular, Solano Garcia (2006) considers a Downsian model with exogenous differences in the party's migration preferences, whereas Llavador and Solano-Garcia (2011) build an endogenous party formation model in which immigration is the salient electoral issue.
} 
agency model in which an incumbent politician sets in each period an official migration target, which will be publicly announced, and chooses the level of enforcement, which is not directly observed by the electorate. At the end of the first period, based on the official immigration target and on the number of immigrants actually in the country, the native population decides whether to re-elect the politician or replace him. In the second period, the supply of foreign workers is known, and the world ends. Importantly, the key player in the election is the median voter, whereas the politician might be of one of two types, which is unknown to the median voter at the time of the election. In particular, he can either be a populist, and share the very same preferences as the median voter, or he can be utilitarian, and have the same preferences as the average voter (i.e. his objective function is aggregate welfare). Assuming - as it is standard in this literature - that the median voter owns a lower share of capital than the average voter, due to complementarities in production between labor and capital the median voter will prefer to admit fewer immigrants than the average voter. If the politician in power is a populist, he will always set the target at the level preferred by the median voter, and implement the median voter's preferred enforcement level. As a result, he will be re-elected to office at the end of the first period. In this case illegal immigration can only arise if there is a positive immigration supply shock, and it is the result of the underlying uncertainty on the supply of foreign workers. In the more interesting case in which the politician in power is instead utilitarian, he might play strategically, in order to have a chance of being re-elected. He might do so because, by being in power in the second period, he will be able to implement his first best policy when the uncertainty on the supply of foreign workers is revealed. Therefore, the benevolent politician might find it optimal to try and "pool" with the populist one, with the goal of inducing the median voter into believing that he is actually a populist. In particular, one possible strategy entails investing in enforcement the amount that would enable the politician to admit in the country under the low state of the world the same number of foreign workers that would have been admitted by a populist politician under the high state of the world. By doing so, if ex post the actual supply of foreign workers is low, the utilitarian politician will be re-elected and a moderate inflow of illegal immigrants will take place. On the other hand, if the supply of immigrants is high, a large inflow of illegal foreign workers will occur, the true preferences of the politician will be discovered, and he will be replaced in the elections at the end of the period. Thus, the model by Facchini and Testa (2012) can rationalize the large number of illegal immigrants observed in some destination countries as the result of a gap in preferences between an elected politician and the median voter, uncertainty on the supply of foreign workers and the superior information available to the politician on the extent of resources invested in policy enforcement. Interestingly, the model is also able to shed light on some important differences that exist across countries in the size of illegal immigration, focusing on drivers on the demand side of the analysis. In fact, the analysis suggests that in more unequal societies - i.e. societies characterized by a greater gap in the capital stock ownership between the average and the median voter - the equilibrium with underinvestment is more likely to emerge. This might help explaining why -ceteris paribus -countries like the United States have more illegal immigrants than countries like Germany. Furthermore, Facchini and Testa (2012) also highlight the potential role played by institutional differences in shaping policy outcomes. In particular, they show that in 
countries where populist pressures are higher, the equilibrium with underinvestment is more likely to emerge, as a benevolent politician will try as hard as possible to be re-elected at the end of the first period, in order not to be replaced by a politician with preferences that differ from his own.

The model developed by Facchini and Testa focuses on the role played by elections in shaping the size of illegal immigration. As it is well known (see Facchini, Mayda and Mishra 2011), the lobbying activities carried out by organized interest groups do influence immigration policy across the board, and are also very likely to affect the pervasiveness of illegal immigration. We will look next at models that have highlighted the role of pressure groups.

\subsubsection{A lobbying model}

To formally study how pressure groups shape policy towards international factor mobility, Facchini and Willmann (2005) develop a simple theoretical model, which is based upon the menu auction framework pioneered by Bernheim and Whinston (1986). In their setting, policy is determined as the result of the interaction between organized groups - representing production factors - who maximize the net welfare of their members, and an elected politician who trades off aggregate welfare vis a vis political contributions. Using a one good multiple factors framework, Facchini and Willmann (2005) find that policies depend both on whether a production factor is represented or not by a lobby and on the degree of substitutability/complementarity between domestic and imported factors. In particular, first they show that a non-organized factor will not be able to influence the policy determination process. Secondly, an organized factor will instead be effective in reducing the inflow of a substitute, while it will increase the inflow of a complement. A lobbying model has also been studied by Epstein and Nitzan (2006), in a setting in which two groups compete against each other to determine the policy and the role played by the existing status quo migration policy is highlighted. These models are able to rationalize both the intense lobbying activities recently carried out - for example - by healthcare providers in the United States - which resulted in the introduction of the new H1C visa category for nurses in 1999 - and the fierce opposition of the union representing local nurses (Facchini, Mayda and Mishra 2011). At the same time, they do not focus directly on illegal immigration.

An interesting first attempt at modeling the effects of pressure group activities in shaping policy towards illegal immigration is instead represented by Chau (2003). In that paper, the author considers an economy made up by two sectors. In the advanced sector only domestic workers can be employed, as there is a need for country-specific human capital. In the agricultural sector instead both domestic and foreign low skilled workers can be employed. One important simplification of the analysis is that all foreign workers in the country are assumed to be illegal - in other words, an official immigration policy and its enforcement are not explicitly considered in Chau's (2003) framework. Two lobbies are assumed to be active, one representing domestic employers, the other domestic workers. As in Facchini and Willmann (2005), the organized groups maximize the interest of their members, and the lobby representing domestic employers is 
keen on having more foreign workers, whereas the opposite is true for the lobby representing domestic workers. In a setting in which free migration would maximize social welfare, Chau shows that the presence of organized groups leads to immigration policy outcomes that take into account the negative effects of illegal immigration on domestic workers, rather than aggregate welfare. Furthermore, she shows that the optimal mix of domestic and border enforcement identified by Ethier (1986) in his pioneering contribution will not be generally chosen in equilibrium for any given immigration target. Instead, employers' sanctions will only be put in place if the negative effects of illegal immigration on wages of native workers exceed a certain threshold. This result highlights how lobbying activities by domestic employers might actually influence the choice of policy tools to be implemented. Chau's analysis also considers the possibility of introducing amnesties as part of the immigration policy package, as a possible way of dealing with an existing stock of illegal immigrants. In the next sections we will take a closer look at the instruments available to the host country government to deal with the existing stock of undocumented foreign workers.

\section{How do governments deal with illegal immigrants?}

The number of illegals who reside in a country reflects that country's policy stance, both in terms of the ex-ante controls introduced to discipline the flows, and the ex-post measures taken to deal with existing stocks. To control the number of illegal immigrants, destination countries can rely on one or more of the following policy tools: they can enforce stricter border controls in an attempt to prevent the entry of unauthorized migrants or strengthen sanctions on employers who hire them, to discourage the demand of illegal immigrants. They can expel and deport undocumented immigrants, if they have managed to enter the country; finally, they can decide to grant undocumented migrants legal status, resorting to migration amnesties or regularization programs. ${ }^{3}$

In the US, the amount of resources devoted to external and internal controls has increased substantially over the past ten years. According to data from the US Department of Management and Budget, the resources allocated to border patrol almost tripled between 2000 and 2010, growing from 1055 million dollars to 2958 million dollars. Despite this large increase, the trend in the number of illegal immigrants has been upward, as noted by Bhagwati and Rivera-Batiz (2012), who argue that the irregular migration pressure is the main determinant of the observed stocks. Indeed, Passel and Cohn (2011) argue that the recent decline in the stock of unauthorized migrants from its 2007 peak is due to the reduction in the inflow from Mexico, the major source country for illegal immigration to the US.

There are a number of contributions which try to assess the effectiveness of border enforcement in curbing unauthorized arrivals. Hanson and Spilimbergo (1999) find that increased border enforcement does cause more border apprehensions in the US, while having a modest deterrence impact: potential migrants react to tighter controls by raising the number of attempts to cross the border, by hiring smugglers or by

\footnotetext{
${ }^{3}$ These policies can of course also be used in combination. For instance, in a recent paper Auriol and Mesnard (2013) investigate the simultaneous use of migration policy enforcement measures and the sale of visas to curb the role of smugglers of illegal immigrants.
} 
choosing different entry points. Importantly, when demand for undocumented labor is high, authorities are willing to relax border enforcement, as shown by Hanson and Spilimbergo (2001) who suggest that this is due to the lobbying activities of industries employing irregular labor. Donato, Durand and Massey (1992) find that the stricter enforcement provisions contained in the 1986 Immigration Reform and Control Act (IRCA) did not reduce irregular flows from Mexico. Similarly, Gathmann (2008) finds that the effect of border enforcement on the number of irregular migrants is small, even if it has an impact on the border crossing points chosen by the immigrants. In a more recent paper, Bohn and Pugatch (2014) tackle the same question, but from a slightly different perspective, i.e. one that involves the effect of border enforcement on the spatial distribution of illegal migrants in the United States. Interestingly, they find that much of the decline in the recent share of illegal immigrants locating in California and Texas can be explained by the increase in the enforcement activities along the Mexico-United States border.

Another policy tool that has an impact on the stock of illegals is represented by deportations. The number of removals has increased under the Obama compared to the Bush administration. According to the US Immigration and Customs Enforcement data, in 2013 approximately 369,000 individuals have been removed from the US, the majority of which were apprehended along the borders while attempting to enter unlawfully the US. While most of the removals in the past were accomplished by apprehending noncitizens who had not committed any crime, but who had either crossed the border illegally or had entered legally but overstayed their visas, during the last years the trend in the data on deportations has been mostly influenced by the removal pace of criminal aliens. The dynamics is instead inverted if we look at the UK where, according to data from the Home Office, removals decreased from approximately 67,000 in 2009 to 60,000 in 2011. At the European Union level, according to the Directorate on Home Affairs, in 2009 the number of irregularly staying non-EU nationals apprehended in the EU was about 570,000, 7 \% less than in 2008.

Even though removals and repatriations are implemented, they are generally considered to be financially very costly, and thus can only be part of a broader strategy to deal with illegal immigration. For example, Fitz, Martinez and Wijewardena (2010) estimate that the total cost of deporting the US undocumented immigrant population and continue the current border interdiction and interior enforcement efforts over a five-year period, would amount to 285 billion US dollars, or 922 US dollars in new taxes for every man, woman, and child in the country. There is also some evidence that the usage of this policy tool might be dictated by political economy considerations. Focusing on Italian provinces, Fasani (2009) analyzes the impact of changes in labor demand on the intensity of government's intervention on unauthorized migrants. He finds that a $1 \%$ increase in local employment causes a $10-15 \%$ reduction in the number of deportations from the area. Bhagwati and Rivera-Batiz (2012) argue that different states in the US have different attitudes towards undocumented immigrants, which are then reflected in the policies that the state and local authorities establish towards them. According to their calculations, while border states (California, Texas, Arizona and New Mexico) hosted approximately $75 \%$ of the total number of undocumented migrants in 1986, in 2000 the same share had fallen to 45\%, with the other states, led by New York, New Jersey and Florida, absorbing the remaining share. These shifts in the settlement patterns reflect different degrees of 
enforcement of migration policy across US states (Bohn et al. 2013). This is also consistent with the dynamics of illegal immigration controls and resettlement described in Djajic (1999), who argues that efforts to control illegal immigrants in sectors where they traditionally find employment may trigger the formation of networks supporting the presence of irregular foreign workers in new locations and occupations, where the probability of detection is comparatively low.

In studying the effect of policies to deter illegal migration, some recent contributions explicitly analyze the decision to migrate illegally in the presence of liquidity constraints. Friebel and Guriev (2006) analyze the role of smugglers as financial intermediaries for credit-constrained migrants. In particular, in their setting migrants enter temporary servitude contracts with the smugglers until they can repay the loan they have received to finance their relocation abroad. Under the assumption that these types of contracts are easier to enforce in the illegal rather than in the legal sector, Friebel and Guriev show that the adoption of stricter deportation policies, which make the transition from the illegal to the legal sector more costly, reduce the likelihood that financially constrained migrants will default on their debt. This increases the incentives for smugglers to lend money to undocumented migrants and as a result stricter deportation policies may, exante, increase rather than decrease the flow of illegal migrants. In addition, they negatively influence the skill composition of migrants since they discourage the inflow of high-skill, high-wealth individuals, who value moving into the legal sector the most when taking their migration decision. As to stricter border controls, they decrease overall immigration but they may result in an increase of debt-financed migration. If the enforcement of migration policy involves also the usage of employers' sanctions, Friebel and Guriev (2006) show that there are complementarities between raids on employers and stricter deportations: the stronger the employer sanctions, the less important is the positive effect of deportation policy on debt-financed migration. Hence, deportation policies may become a more effective tool for decreasing migration. Djajic and Vinogradova (2014) build on Friebel and Guriev (2006) and contrast the debt-financed illegal migration decision studied in Friebel and Guriev (2006) with the case in which it is self-financed. In particular, they analyze how the incentives to resort to each of these instruments is influenced by the source country's migration policies. They show that more restrictive border-control measures can reduce the incidence of debt-bonded migration. Depending on the wage gap between the host and source countries, however, such measures may simply induce foreigners to switch from debt-bonded to self-financed migration, rather than reduce the total undocumented inflows. As to internal enforcement measures, again they can be expected to reduce the incidence of debt-bonded relative to self-financed migration, but they reduce the overall inflow of undocumented workers as long as they increase the costs and risks of debt-bonded contracts and therefore raise the wedge between the free market wage and the debt-bonded wage. The role of alternative policy instruments in deterring debt-bonded migration is studied also in Djajic and Vinogradova (2013).

Ex post, host country governments can also use legalization programs to "wipe the board clear" of illegal immigration. Amnesties have been the focus of much attention, and much controversy. Some countries have never resorted to general amnesties (e.g. Germany and the United Kingdom), whereas some others have made it a very frequently used instrument. For instance, this has been the case of Spain, which 
has introduced six times a broad legalization program between 1980 and 2008, or Italy, which has also often resorted to general legalization programs. A general regularization program has obviously a direct impact on the estimated stock of illegals, which is greatly reduced right after legalization. For instance, the 1986 amnesty introduced in the US with the IRCA lead to approximately 3.5 million legalizations (Facchini and Testa 2012), and Dolado (2007) has convincingly argued that in the case of Spain during the Nineties, about $98 \%$ of the legal foreign residents had been illegally living in the country at some point. What drives the decision of a country to implement a broad amnesty program? We turn to this question in the next section.

\section{What drives the legalization decision?}

The literature that aims at explaining the introduction of immigration amnesties is small, but several recent papers have started to shed light on the issue.

In an early contribution, Chau (2001) shows that legalizing undocumented workers can be part of an optimal migration policy package - together with internal and border controls - when there is a time inconsistency problem because the government cannot commit to implement the ex-ante optimal frequency of internal controls. Importantly, in her model all workers share the same skill level and all immigrants are ex--ante undocumented. They can become legal only as a result of an amnesty. ${ }^{4}$ Karson and Katz (2003) develop instead a model of illegal immigration focusing on the role of amnesties as a tool for governments to induce immigrants to self-select based on ability. In particular, they emphasize that a legalization will offer skilled workers better labor market opportunities. As a result, the latter might be enticed to migrate even as illegals, in the hope that an ex--post legalization will improve their income opportunities.

Epstein and Weiss (2011) also study the desirability of legalization programs. In their setting, immigrants can only enter the country illegally, and can become legal as the result of an amnesty. Immigration is always costly from the destination country's point of view and the cost depends only on the total number of immigrants, and not on their skill level. Moreover, migrants earn the same wages irrespective of their status. While this literature has highlighted the role of important forces at play, it faces some significant challenges. First and foremost, in these models foreigners can only enter the country as illegal - in other words these models do not allow for the entry of legal migrants together with illegal migrants. Moreover, some of the labor market assumptions do not appear particularly realistic: as it has been shown in the empirical literature, the wages of legalized migrants do improve following an amnesty (Kossoudji and Cobb-Clark 2002 and Kaushal 2006). In addition, the skill level of the illegal migrant is likely to be a key determinant of the welfare consequences of a legalization program.

To account for these important forces, Casarico, Facchini and Frattini (2014) have developed a new theoretical model of the determinants of general amnesty programs, and have empirically assessed its performance on a panel of OECD countries. In particular, setting up a two-period model, they assume that the destination country's immigration policy involves the determination - under imperfect information on the

\footnotetext{
${ }^{4}$ For a political economy model of immigration amnesties, see also Chau (2003).
} 
future state of the world - of a minimum skill requirement which cannot be perfectly enforced. The lack of an adequate enforcement technology implies that illegal immigration might arise, while the presence of uncertainty implies that the minimum skill requirement chosen ex-ante might turn out to be ex-post suboptimal, making the introduction of a legalization program potentially desirable. In establishing whether an amnesty might be ex-post desirable, the cost-benefit calculus involves a comparison between the potential improvement in domestic income resulting from the new labor market opportunities opened to legalized migrants thanks to a better match of migrants' skills with firms' skill requirements, and the costs of a welfare state leakage from natives to migrants.

What is the optimal migration policy from the destination country's point of view? To fix ideas, Casarico, et al. (2014) start by considering the case in which there is no uncertainty about the second period state of the world, where uncertainty refers to the share of income appropriated by natives in the economy. In this case, a government which aims at maximizing natives' aggregate welfare will admit a higher number of legal migrants, the higher is the share of output accruing to natives in the formal sector. The intuition is simple: since legal immigrants can work in the formal sector while illegal immigrants are confined to the underground economy, when natives can appropriate a larger share of output from the formal sector, then they will prefer having more immigrants employed there. A legalization is never introduced because in the absence of uncertainty the government of the receiving country can ex-ante identify the marginal migrant who equates the marginal benefits of an increase in expected output with the marginal cost of granting access to the welfare state. In the more realistic case in which the government does not know ex-ante the second period state of the world, it may use a legalization program to mitigate the adverse effects of an excessively restrictive policy implemented in the first period. Casarico et al. (2014) also show that an amnesty is more desirable the greater is the improvement in the labor market opportunities available to legalized workers as a result of them gaining access to the formal sector, and the less redistributive the welfare state is. They also show that a legalization may be undertaken only when a shock increases natives' bargaining power in the formal sector so as to undo the higher costs they have to bear by allowing legalized immigrants access to the welfare state.

Do the channels highlighted in the theoretical analysis matter empirically? To answer this question, the authors have built a panel dataset covering 17 OECD countries over the period $1980-2007^{5}$ which based on legalization episodes recorded by SOPEMI- reports information on whether in a given year a country has introduced an amnesty. These data are matched with proxies for each of the main drivers considered in the model. Shocks to natives' bargaining power are proxied with trade shocks. In particular, the attractiveness of domestic exports is captured by the real effective exchange rate (REER), a measure of the value of a currency against a weighted average of the currencies of a country's trade partners. It is defined so that an increase in its value represents an appreciation of the home currency, which leads to a decline in the home country's competitiveness and thus in the workers' bargaining power. Second, to capture

\footnotetext{
${ }^{5}$ The countries included in the sample are Austria, Belgium, Canada, Denmark, France, Germany, Greece, Ireland, Italy, the Netherlands, Norway, Portugal, Spain, Sweden, Switzerland, the UK, and the US.
} 
the quality of the labor market match which could potentially be improved by granting legalized migrants wider employment opportunities, since separate indicators for legal and illegal migrants cannot be formulated, they rely on a proxy for the overall labor market matching technology based on the share of workers that are under- or over- educated (for a discussion of this type of indices see e.g. Chevalier 2003, Verdugo and Verdugo 1988) starting from annual microdata. Finally, they proxy the extent of redistribution carried out by the welfare state with public expenditure on unemployment benefits as a share of GDP, taken from the OECD Social Expenditure Database. As Boeri, Hanson, and McCormick (2002) show, unemployment benefits are one of the transfer programs that are used most by immigrants. All regressions also include additional control variables potentially correlated with the decision to grant an amnesty, such as the number of asylum applications, a measure of the incidence of criminal activities, per capita GDP growth, the old age dependency ratio, and a dummy for the government's political orientation as well as year and country dummies

The results show that there exists a positive and statistically significant relationship between the REER and the probability of having an amnesty, which supports the conclusions from their model that amnesties are more likely, the higher the natives' bargaining power in the formal sector. As regards the two main channels identified in their theoretical model, there is a strong positive correlation between the labor market mismatch index and the probability of an amnesty, suggesting that amnesties are more likely to occur the larger are the output gains from giving migrants access to the full set of jobs.. Further, a higher level of public spending on unemployment as a share of GDP is negatively and significantly correlated with the probability of an amnesty. These findings thus suggest that the channels identified in the theoretical model play a statistically significant and economically relevant role in shaping the introduction of amnesty programs.

\section{Conclusion}

In this paper we have studied what drives the setting of policies towards irregular migrants. We started by arguing that in democratic societies the preferences of citizens are the primitives of the policy maker's problem. Given these preferences and the way they are aggregated, the observed number of irregular migrants depends on the policy maker's behavior and on the institutional environment in which he operates. In a setting where the median voter dominates the political process, we have suggested that irregular migration can arise because of the presence of uncertainty on the inflow of migrants and/or because of the fact that politicians, with preferences that differ from those of the median voter, might strategically underinvest in policy enforcement as to increase the probability of being re-elected. Similarly, despite an official anti-migration rhetoric, the lobbying activities of pro-migration groups might also increase the number of illegal immigrants admitted.

Differences in the ex-ante policies adopted lead to flows and stocks of irregular migrants that greatly vary across countries, and national governments have adopted widely heterogeneous policies also to manage irregular immigration ex-post. After having surveyed the theoretical and empirical literature on policies to 
curb illegal immigration, we have focused on regularization programs andwe have presented some recent empirical work which shows that in the presence of trade shocks, labor market characteristics of the host country and the extent of redistribution carried out by the welfare state play a key role in shaping the probability of introducing an amnesty.

Countries in the European Union are among the recipients of the larger inflows of immigrants. As a result, important policy spillovers across member countries could occur, and should be taken into account by decision makers in the formulation of their strategy towards illegal immigration. The role played by crossborder migration externalities has been recognized in several studies in the literature. In a series of papers on asylum seekers, Hatton $(2011,2009,2004)$ argues that, since the benefits from protecting refugees are not enjoyed exclusively by the citizens of the country that accommodates them, this activity has the characteristic of a public good, and as a result it is likely that too few asylum seekers will be admitted in an uncoordinated equilibrium. Facchini, Lorz and Willmann (2006) extend his analysis taking explicitly into account the democratic process through which migration policies are decided. They confirm that there are gains from coordination, but highlight that cost sharing across jurisdictions might not be optimal. Focusing directly on irregular migration, Mayr, Minter and Krieger (2012) look at the spillover effects generated by the decision by one country belonging to a federation to grant an amnesty to the irregular migrants that it hosts. Free mobility across national borders implies that this decision will carry important repercussions on the other member states. Interestingly, they show that spending on enforcement in the country with an external border is always greater than spending on enforcement in the country that does not have an external border. Moreover, a greater rate of onward migration within the federation makes an amnesty more likely in the port of entry, decreasing ceteris paribus enforcement spending, while it increases the spending of the country that does not have an external border. Importantly, they conclude by highlighting that total enforcement spending in the decentralized equilibrium is suboptimal, thus pointing out once again the need for coordination to improve outcomes.

The European Union and the EU Commission have started to recognize the need for further coordination in the immigration policy area. Today, two are the main areas where a common stance is followed towards the nationals of non-EU countries: the policy towards refugees and asylum seekers through the European Refugee Fund, and the protection of the external borders via Frontex. The emphasis on the need to coordinate border enforcement policies among member states has been particularly stressed, although many observers have noted that most irregular migrants living in the EU originally entered the area legally, and have overstayed their visas (Triandafyllidou and Vogel 2010). In other words, what is needed is not only greater coordination of border control, but even more importantly there must be more coordination in the domestic enforcement of existing immigration policies. The big question for policy makers is whether such a step is politically feasible.

Shen (2012) has recently considered several waves of the Eurobarometer survey carried out between 2000 and 2008 to study EU citizen's preferences towards the allocation of decision making powers in the 
immigration policy area. ${ }^{6}$ Interestingly, she finds that on average, 55\% of the individuals interviewed support joint decision making, but that there are large differences across countries. In Spain, Italy and Malta citizens are particularly in favor of joint decision making. These countries represent the EU southern external border and are the most exposed to irregular flows. Citizens of Finland (20\%) and Great Britain (33\%), on the other hand, show the lowest inclination to transfer decision making on migration issues at the European level. Importantly, Shen (2012) finds that more educated citizens are more likely to support transferring the policy making power to the EU level.

The key challenge for Europe in the area of policy towards irregular migration is to further enhance the cooperation among member states. At the grass-root level, there seems to be wide support for more coordination. The open question for policy makers involves insuring that the majority's preferences are adequately represented at the institutional level, and individual country's vetoes do not make further coordination impossible.

${ }^{6}$ The exact wording of the Eurobarometer question is "For each of the following areas, do you think that decisions should be made by the (nationality) Government, or made jointly within the European Union?" 


\section{References}

Auriol E. and A. Mesnard (2013) "Sale of visas: A smuggler's final song?" Working Paper 13/06, Department of Economics, City University London.

Bhagwati J. and F. Rivera-Batiz (2012) "Shifting the lens" mimeo, Columbia University.

Benhabib, J. (1996) “On the Political Economy of Immigration” Economic European Review 40: 1737-1743.

Berg, J.A. (2009) "White public opinion toward undocumented immigrants: Threat and interpersonal environment" Sociological Perspectives 52:39-58.

Bernheim, B.D. and M.D. Whinston (1986) "Menu auctions, resource allocation and economic influence" Quarterly Journal of Economics 101:1-31.

Blonigen B. (2011) "Revisiting the evidence on trade policy preferences" Journal of International Economics 85:129-135.

Boeri, T., G. Hanson, and B. McCormick (2002) "Immigration policy and the welfare system" Oxford University Press.

Bohn S., M. Lofstrom and S. Raphael, (2013) "The Effects of State-Level Legislation Targeted Towards Limiting the Employment of Undocumented Immigrants on the Internal Composition of State Populations: The Case of Arizona" forthcoming in the Review of Economics and Statistics.

Bohn S. and T. Pugatch (2014) "US border enforcement and Mexican immigrant location choice" mimeo, Public Policy Institute of California

Borjas, G. J. (1999) "The economic analysis of immigration", chapter 28 in "Handbook of Labor Economics" in "Handbook of Labor Economics", Volume 3A, edited by Orley Ashenfelter and David Card, North-Holland, 1999

Casarico, A., G. Facchini and T. Frattini (2014) “What drives immigration amnesties?”, mimeo.

Ceobanu, A. M. and X. Escandell (2010) "Comparative analyses of public attitudes toward immigrants and immigration using multinational survey data: A review of theories and research" Annual Review of Sociology 36: $309-328$

Chau, N. (2001) "Strategic amnesty and credible immigration reform." Journal of Labor Economics 19: 604-634

Chau, N. (2003) "Concessional amnesty and the politics of immigration reform" Economics and Politics 15: 193-224.

Chevalier, A. (2003) “Measuring over-education” Economica 70: 509-531.

Djajic, S. (1999) “Dynamics of immigration control” Journal of Population Economics 12(1): 45-61.

Djajic, S. and A. Vinogradova (2013) "Undocumented Migrants in Debt", Labour Economics 21:15-24.

Djajic, S. and A. Vinogradova (2014) "Liquidity-Constrained Migrants" , Journal of International Economics, 93: 210-224.

Dolado, J. J. (2007) “The Spanish approach to immigration” Vox. 
Donato, K.M., J. Durand and D.S. Massey (1992) "Stemming the tide? Assessing the deterrent effects of the Immigration Reform and Control Act” Demography 29(2): 139-157.

Dumont, M., G. Rayp, and P. Willeme (2006). "Does internationalization affect union bargaining power? An empirical study for five EU countries”, Oxford Economic Papers, 58, 77-102.

Dustmann, C. and T. Frattini (2013). "Immigration: the European Experience", chapter 13 in "Immigration, Poverty, and Socioeconomic Inequality", edited by D. Card and S. Raphael, Russell Sage Foundation.

Dustmann, C. and I. Preston (2007). "Racial and economic factors in attitudes to immigration". The B.E. Journal of Economic Analysis \& Policy 7, Article 62.

Dustmann, C. and I. Preston (2001). "Attitudes to ethnic minorities, ethnic context, and location decisions". Economic Journal 111, 353-373.

Epstein, G.S. and S Nitzan. (2006). "The struggle over migration policy" Journal of Population Economics 19: 703-723.

Epstein, G. S. and A. Weiss (2011)."The why, when, and how of immigration amnesties."Journal of Population Economics 24:285-316.

Espenshade, T. J. and C.A. Colahun (1993) "An analysis of public opinion towards undocumented immigration" Population Research and Policy Review 12:189-224.

Ethier, W.J. (1986) “Illegal immigration: The host country problem” American Economic Review 76: 56-71.

Facchini, G. and A.M. Mayda (2010) "What drives immigration policy? Evidence based on a survey of government's officials" in I. Gang and G. S. Epstein (eds) Culture and Migration (Frontiers of Economics and Globalization, Volume X), World Scientific, pages 605-648.

Facchini, G. and A. M. Mayda (2009). "Individual attitudes towards immigrants: Welfare state determinants across countries" Review of Economics and Statistics 91: 291-314.

Facchini, G., A.M. Mayda and P. Mishra (2011) “Do interest groups affect US immigration policy?” Journal of International Economics 85: 114-128.

Facchini, G., A.M. Mayda and R. Puglisi (2011) "Illegal immigration and media exposure: Evidence on individual attitudes", mimeo.

Facchini, G. and C. Testa (2012) "The rhetoric of closed borders: quotas, lax enforcement and illegal immigration" CEPR WP 8245.

Facchini, G. and G. Willmann (2005) "The political economy of international factor mobility" Journal of International Economics 67: 201-219.

Fasani, F. (2009) "Deporting undocumented immigrants: The role of labor demand shocks" mimeo, University College London.

Fasani, F. (2010) "The quest for "La Dolce Vita"? Undocumented migration in Italy", in Triandafyllidou A. (edited by) Irregular Migration in Europe: Myths and Realities, Ashgate.

Fino R. (2010) "Does the illegal status affect attitudes towards immigrants? A cross-country analysis of individual preferences" mimeo, Universita' degli Studi di Milano.

Fitz, M., G. Martinez and M. Wijewardena (2010) "The cost of mass deportation" Center for American Progress. 
Friebel G. and S. Guriev (2006) "Smuggling Humans: A Theory of Debt-financed Migration" Journal of the European Economic Association 6:1085-1111

Gathmann, C. (2008) "Effects of enforcement on illegal markets: Evidence from migrant smuggling at the southwestern border" Journal of Public Economics 92: 1926-1941.

Hainmueller, J. and M. J. Hiscox (2007). "Educated preferences: Explaining attitudes toward immigration in Europe". International Organization 61: 399-442.

Hanson, G., K. Scheve, and M. Slaughter (2007). "Public Finance and Individual Preferences over Globalization Strategies" Economics and Politics 19:1-33.

Hanson G. H. and A. Spilimbergo (2001) "Political economy, sectoral shocks and the border enforcement" Canadian Journal of Economics 34: 612-638.

Hanson, G. H. and A. Spilimbergo, (1999) "Illegal immigration, border enforcement, and relative wages: Evidence from apprehensions at the U.S.-Mexico border”, American Economic Review 89: 1337-1357.

Hatton, T. J. (2011) "Seeking Asylum: Trends and policies in the OECD countries" London: CEPR.

Hatton, T. J. (2009) "The rise and fall of asylum: What happened and why?" Economic Journal 119: 183213.

Hatton, T. J. (2004) "Seeking asylum in Europe” Economic Policy 19:5-62.

ISSP Research Group (2012) International Social Survey Programme: National Identity II - ISSP 2003. GESIS Data Archive, Cologne. ZA3910 Data file Version 2.1.0, doi:10.4232/1.11449

Joppke, L. (1998) “Why liberal states accept unwanted immigration” World Politics 50: 266-293.

Karlson S.H. and E. Katz (2003) "A positive theory of immigration amnesties". Economic Letters 78:231239.

Kaushal,N. (2006). “Amnesty programs and the labor market outcomes of undocumented workers.”Journal of Human Resources 41: 631-647.

Killias, M., M. F. Aebi, K. A. B. Aubusson de Cavarlay, G. Barclay, B. Gruszczyska, H. Von Hofer, V. Hysi, J. M. Jehle, P. Smit, and C. Tavares (2010) "European Sourcebook of Crime and Criminal Justice Statistics" (Fourth ed.). Meppel.

Kossoudji, S. A. and D. Cobb-Clark (2002). "Coming out of the shadows: Learning about legal status and wages from the legalized population.”Journal of Labor Economics 20: 598-628.

Llavador, H. and A. Solano Garcia (2011) "Immigration policy with partisan parties", Journal of Public Economics 95: 134-142.

Mayda, A. M. (2006). "Who is against immigration? A cross-country investigation of individual attitudes toward immigrants." Review of Economics and Statistics 88: 510-530.

Mayr, K., S. Minter and T. Krieger (2012) "Policies on illegal immigration in a federation", Regional Science and Urban Economics, 42: 1-2.

Mueller, T. and S. Tai (2009). Individual Attitudes towards Migration: A Re-Examination of the Evidence. Mimeo, University of Geneva.

Ortega, F. (2005). “Immigration Quotas and Skill Upgrading.” Journal of Public Economics 89: 1841-1863. 
Ortega F. and J. Polavieja (2012) "Labor-market Exposure as a Determinant of Attitudes toward Immigration." Labour Economics, 19: 298-311.

Passel J.S. and D.V. Cohn (2011) "Unauthorized Immigrant Population: National and State Trends, 2010" Mimeo, Pew Hispanic Center, Washington DC.

Rodrik, D. (1995) "Political Economy of Trade Policy." Chapter 28 in The Handbook of International Economics, vol. 3, eds. G. Grossman and K. Rogoff. Amsterdam: North-Holland, pp. 1457-1494.

Rodrik, D., (1997) “Has Globalization Gone Too Far?”, Institute for International Economics, Washington DC.

Scheve, K. F. and M. J. Slaughter (2001) "Labor market competition and individual preferences over immigration policy". Review of Economics and Statistics 83: 133-145.

Schneider, F. (2011) "The shadow economy and shadow economy labor force: What do we (not) know?" Discussion paper 5769, IZA.

Shen, Y. (2012) "Individual attitudes towards the Eurpeanization of immigration policy" mimeo, Universita' degli Studi di Milano.

Slaughter, M. J., (2001). "International trade and labor-demand elasticities", Journal of International Economics, 54: 27-56.

Solano Garcia, A., (2006) "Does illegal immigration empower rightist parties?", Journal of Population Economics, 19: 649-670.

SOPEMI (2011) “International Migration Outlook 2011” Paris: OECD.

Triandafyllidou, A. and D. Vogel (2010) "Irregular Migration in Europe: Myths and Realities" Ashgate.

Verdugo, R. R. and N. T. Verdugo (1988) "Overeducation and the earnings of black, hispanic, and white male workers" Sociological Perspectives 3: 190-212.

Wunderlich, T., A. Ziebarth, D. Gustin, Z. Nyiri, P. Isernia, C. Diehl, and S. Martin (2012) "Transatlantic Trends: Immigration, 2010”, ICPSR33022-v1, Ann Arbor, MI: Inter-university Consortium for Political and Social Research [distributor], 2012-04-03. doi:10.3886/ICPSR33022.v 
Table 1. Estimates of undocumented immigrants, 2009

As a \% of total population

As a \% of immigrant population

\begin{tabular}{l|cc|cc}
\hline Country & Min & Max & Min & Max \\
& & & & $6.5 \%$ \\
Austria & $0.22 \%$ & $0.65 \%$ & $2.2 \%$ & $14.2 \%$ \\
Belgium* & $0.82 \%$ & $1.24 \%$ & $9.4 \%$ & $1.7 \%$ \\
Denmark* & $0.02 \%$ & $0.09 \%$ & $0.3 \%$ & $11 \%$ \\
France* & $0.28 \%$ & $0.63 \%$ & $4.9 \%$ & $6.3 \%$ \\
Germany & $0.24 \%$ & $0.56 \%$ & $2.7 \%$ & $19.2 \%$ \\
Greece & $1.53 \%$ & $1.86 \%$ & $9.1 \%$ & $13.8 \%$ \\
Ireland* & $0.68 \%$ & $1.41 \%$ & $6.7 \%$ & $15.7 \%$ \\
Italy & $0.47 \%$ & $0.77 \%$ & $9.5 \%$ & $19.2 \%$ \\
Netherlands* & $0.38 \%$ & $0.8 \%$ & $9.1 \%$ & $23 \%$ \\
Portugal* & $0.75 \%$ & $0.94 \%$ & $18.4 \%$ & $2.7 \%$ \\
Spain* & $0.62 \%$ & $0.78 \%$ & $6.1 \%$ & $23.6 \%$ \\
Sweden & $0.09 \%$ & $0.13 \%$ & $1.6 \%$ & $11.9 \%$ \\
UK & $0.68 \%$ & $1.41 \%$ & $11.4 \%$ & \\
EU-15* & $0.46 \%$ & $0.83 \%$ & $6.6 \%$ & $28.4 \%$ \\
USA & & & & \\
\hline \hline
\end{tabular}

*denotes low quality estimates

Source: Dustmann and Frattini (2013) 
Table 2. Attitudes towards legal and illegal immigration (ISSP 2003)

\begin{tabular}{l|cccc}
\hline \hline & $\begin{array}{c}\text { Average Pro } \\
\text { Immigration }\end{array}$ & $\begin{array}{c}\text { Median Pro } \\
\text { Immigration }\end{array}$ & $\begin{array}{c}\text { Average Pro Ill. } \\
\text { Immigation }\end{array}$ & $\begin{array}{c}\text { Median Pro Ill. } \\
\text { Immigration }\end{array}$ \\
\hline Australia & 2.73 & 3 & 2.06 & 2 \\
Austria & 2.10 & 2 & 1.81 & 1 \\
Bulgaria & 2.19 & 2 & 1.35 & 1 \\
Canada & 2.85 & 3 & 1.77 & 2 \\
Chile & 2.24 & 2 & 2.16 & 2 \\
Czech Republic & 1.98 & 2 & 1.57 & 1 \\
Denmark & 2.32 & 2 & 1.86 & 1 \\
Finland & 2.76 & 3 & 1.88 & 2 \\
France & 2.00 & 2 & 2.11 & 2 \\
Germany & 1.85 & 2 & 1.78 & 2 \\
Great Britain & 1.79 & 1 & 1.73 & 1 \\
Hungary & 1.96 & 2 & 1.56 & 2 \\
Ireland & 2.24 & 2 & 2.03 & 1 \\
Japan & 2.40 & 2 & 1.56 & 2 \\
Latvia & 2.19 & 2 & 1.81 & 2 \\
Netherlands & 1.95 & 2 & 1.84 & 1 \\
New Zealand & 2.35 & 2 & 1.64 & 1 \\
Norway & 1.98 & 2 & 1.60 & 2 \\
Poland & 2.30 & 2 & 2.37 & 2 \\
Portugal & 2.33 & 2 & 2.37 & 2 \\
Russia & 1.72 & 1 & 1.74 & 2 \\
Slovak Republic & 2.20 & 2 & 1.68 & 2 \\
Slovenia & 2.35 & 2 & 1.98 & 2 \\
Spain & 2.46 & 2 & 2.64 & 2.11 \\
Sweden & 2.29 & 2 & 2.05 & 2 \\
Switzerland & 2.47 & 3 & 2.15 & 2 \\
United States & 2.33 & 2 & 1 & 2 \\
\hline \hline
\end{tabular}

The table reports mean and median attitudes pro-immigration (columns 1 and 2) and pro-illegal immigration (columns 3 and 4) for each advanced destination country. The table is based on v55 and v62 in the 2003 round of the International Osical Survey Programme. Variable values range between 1 and 5, and are rescaled so that a higher value corresponds to more favourable attitudes toward immigration. 
Table 3. Attitudes towards legal and illegal immigration (Transatlatic Trends 2010)

\begin{tabular}{l|cc}
\hline \hline & Worried by legal immigration & Worried by illegal immigration \\
\hline Canada & 22.2 & 53.5 \\
France & 18.3 & 59.9 \\
Germany & 28.8 & 58.6 \\
Italy & 26.1 & 83.3 \\
Netherlands & 27.0 & 61.8 \\
Spain & 22.0 & 74.7 \\
United Kingdom & 35.4 & 72.1 \\
United States & 17.7 & 60.5 \\
\hline \hline
\end{tabular}

The table reports the share of each country's population who declares to be worried by legal (column 1) and by illegal (column 2) immigration. The table is based on Q6_1 and Q6_2 in Transatlantic Trends: Immigration, 2010. 